\title{
Simultaneous inclusion of sorghum and cottonseed meal or millet in broiler diets: effects on performance and nutrient digestibility
}

\author{
D. I. Batonon-Alavo ${ }^{1,2 a \dagger}{ }^{\dagger}$ D. Bastianelli ${ }^{3}$, P. Lescoat ${ }^{4}$, G. M. Weber ${ }^{5}$ and M. Umar Faruk ${ }^{2}$ \\ ${ }^{1}$ INRA, UR83 Recherches Avicoles, Nouzilly, France; ${ }^{2}$ Research Centre for Animal Nutrition and Health, DSM Nutritional Products France, Saint Louis, France; ${ }^{3}$ CIRAD, \\ UMR SELMET, Systèmes d'élevage méditerranéens et tropicaux, Baillarguet TA C-112/A, Montpellier Cedex 05, France; ${ }^{4}$ AgroParisTech, UMR 1048 SADAPT, Paris, \\ France, ${ }^{5}$ Nutrition Innovation Center, DSM Nutritional Products Ltd, Basel, Switzerland
}

(Received 8 October 2014; Accepted 14 December 2015; First published online 3 February 2016)

Two experiments were conducted to investigate the use of sorghum, cottonseed meal and millet in broiler diets and their interaction when they are used simultaneously. In Experiment 1, a corn-soybean meal control diet was compared with eight experimental treatments based on low tannin sorghum (S30, S45 and S60), cottonseed meal (CM15, CM40) or both ingredients included in the same $\operatorname{diet}($ S30/CM40, S45/CM25 and S60CM15). Results showed that BW gain was not affected by the inclusion of sorghum or cottonseed meal. However, feed intake tended to be affected by the cereal type with the highest values with sorghum-based diets. Feed conversion ratio increased $(\mathrm{P}<0.001)$ with sorghum-based diets compared with the control diet, whereas a combination of cottonseed meal and sorghum in the same diet did not affect the feed conversion ratio. Significant differences $(\mathrm{P}<0.001)$ were observed in apparent ileal digestibility (\%) of protein and energy with the cottonseed meal and sorghum/cottonseed meal-based diets having lower protein and energy digestibility compared with corn-based diets. In Experiment 2, a control diet was compared with six diets in which corn was substituted at $60 \%, 80 \%$ or $100 \%$ by either sorghum or millet and other three diets with simultaneous inclusion of these two ingredients (S30/M30, S40/M40, S50/M50). Single or combined inclusion of sorghum and millet resulted in similar feed intake and growth performance as the control diet. Apparent ileal digestibility of protein and energy was higher with millet-based diets ( $\mathrm{P}<0.001)$. Total tract digestibility of protein in sorghum and millet-based diets tended to decrease linearly with the increasing level of substitution. Sorghum-based diets resulted in lower total tract digestibility of fat compared with millet and sorghum/millet-based diets $(\mathrm{P}<0.001)$. Higher total tract digestibility of starch were obtained with the control diet and millet-based diets compared with the sorghum-based treatments. Results of the two experiments suggest that broiler growth performance was not affected by the dietary level of sorghum, millet or cottonseed meal. Nutrient digestion can, however, be affected by these feed ingredients.

Keywords: broiler, sorghum, millet, cottonseed meal, digestibility

\section{Implications}

Sorghum, millet and cottonseed meal can be used in poultry nutrition to replace corn and soybean meal. Results showed that the overall performance is not affected when high quality ingredients (low tannin, low gossypol) are used. Some effects on feed intake and feed efficiency were identified and discussed. The present study provides additional knowledge to the use of sorghum, millet and cottonseed meal in commercial poultry production.

\section{Introduction}

The worldwide competitiveness of the poultry industry requires finding alternative to major feed ingredients used in

\footnotetext{
${ }^{a}$ Present address: Adisseo France S.A.S., 03600 Commentry, France.

${ }^{\dagger}$ E-mail: dolores.batonon@gmail.com
}

broiler feeding to reduce the cost of feeding. Sorghum (Sorghum bicolor) and millet (Pennisetum glaucum, Panicum miliaceum) have been widely investigated in broiler nutrition as substitutes to corn. Cottonseed meal (Gossypium spp.) has also been examined as an alternative to soybean meal. Results indicated that similar (Davis et al., 2003; Hidalgo et al., 2004) or improved performance (Baurhoo et al., 2011) was obtained with millet-based diets compared with corn-based diets. Whereas for sorghum and cottonseed meal, a reduction in feed efficiency (Jacobs and Parsons, 2013) or equivalent performance as the control diet were obtained (Jacob et al., 1996; Azman and Yilmaz, 2005).

In a meta-analysis on the use of these feed ingredients (Batonon-Alavo et al., 2015), we observed that millet-based diets gave similar performance as the corn-based diets while cottonseed meal-based diets increased feed intake. Average daily gain was reduced with both sorghum- and cottonseed 
Sorghum, millet and cottonseed meal in broilers

meal-based diets. However, there was no significant doseresponse effect with millet and cottonseed meal. Growth performance decreased with the increasing level of substitution of corn with sorghum.

This reduction in growth performance obtained in sorghum and cottonseed meal-based diets may be related to their content of anti-nutritional factors. According to several authors, tannins and phytate in sorghum form complexes with protein and carbohydrates, particularly with starch, thereby reducing nitrogen and starch digestibility (Selle et al., 2010; Mahmood et al., 2014). Birds fed high tannin diets suffered from a severe decrease of growth compared with low tannin or control fed birds (Flores et al., 1994; Mahmood et al., 2006). In addition, Kafirin has been examined in sorghum by Selle et al. (2010). Its presence in sorghum is associated with a poor amino acid digestibility. In cottonseed meal, free gossypol decreases lysine digestibility and inhibits the activity of pepsin and trypsin, thus reducing growth in broilers (Nagalakshmi et al., 2007).

For more flexibility in the type of ingredients used in the least cost feed formulation, it could be hypothesized that simultaneous utilization of more than one of these alternative feed ingredients in poultry diets will become commonplace. Consequently, the question arises whether simultaneous inclusion of sorghum and cottonseed meal in broiler feeding would result in additive effect or a synergy of the anti-nutritional factors. Besides, the protein content of millet is higher than corn and the essential amino acid profile is more balanced in millet than in corn (Heuzé and Tran, 2012). The high essential amino acid concentrations, the high digestibility of these amino acids (Adeola and Orban, 1995; Yin et al., 2002) and the changes in the small intestine mucosa morphology were reported to be the factors leading to a better feed efficiency with millet (Baurhoo et al., 2011; Goodarzi Boroojeni et al., 2011). It could therefore be assumed that bird's nutrient digestibility increases when millet is used in sorghum-based diets.

This work was, therefore, designed to evaluate the effects of partial or total substitution of corn with sorghum and millet, and partial replacement of soybean meal with cottonseed meal on performance and nutrient digestibility in broiler. It is the aim of this study to investigate the interactions that might be induced on broiler performance when sorghum and cottonseed meal are simultaneously included in the diet or when sorghum and millet totally replaced corn in the diet.

\section{Material and methods}

\section{General}

Two trials were conducted: the first experiment combined sorghum and cottonseed meal and the second one used sorghum and millet. Nutritional composition of these feed ingredients are described in Table 1. The same batch of sorghum (S. bicolor) originating from France was used in the two experiments. It was a sorghum with red pericarp, but without testa layer, and therefore had low condensed tannin
Table 1 Analyzed composition of sorghum (S), cottonseed meal (CM) and millet (M)

\begin{tabular}{lccc}
\hline \hline & Sorghum & Cottonseed meal & Millet \\
\hline Analyzed composition $(\mathrm{g} / \mathrm{kg}$, as fed) & & \\
DM & 864 & 920 & 869 \\
CP & 82.8 & 402 & 116 \\
Crude fat & 35.2 & 25.0 & 45.2 \\
Starch & 631 & 8.70 & 582 \\
Total sugars & 3.80 & 68.6 & 1.20 \\
NDF & 138.6 & 206.6 & 151.9 \\
ADF & 50.8 & 119.1 & 84.2 \\
ADL & 17.3 & 29.9 & 20.0 \\
Condensed tannins & 1.80 & nd & nd \\
Free gossypol & nd & 1.03 & nd \\
ME (MJ/kg) & 13.33 & 7.69 & 13.19 \\
\hline \hline
\end{tabular}

$\mathrm{nd}=$ not determined; $\mathrm{ME}=$ metabolizable energy; $\mathrm{DM}=$ dry matter; $\mathrm{EE}=$ ether extract; $C F=$ crude fibre; NFE = nitrogen free extract.

${ }^{1} \mathrm{ME}$ content was estimated using European energy calculation (Janssen, 1989). $\mathrm{S}(\operatorname{tannin}<4 \mathrm{~g}) \mathrm{MEn}=31.02 \times \mathrm{CP}+77.03 \times \mathrm{EE}+37.67 \times \mathrm{NFE}$; CM expeller or solvent, $\mathrm{MEn}=21.36 \times \mathrm{DM}+47.13 \times \mathrm{EE}-30.55 \times \mathrm{CF} ; \mathrm{M}$ (corn equation), $\mathrm{MEn}=36.21 \times \mathrm{CP}+85.44 \times \mathrm{EE}+37.26 \times \mathrm{NFE}$; with $\mathrm{DM}, \mathrm{EE}, \mathrm{CF}$ and $\mathrm{NFE}=$ $\mathrm{DM}-(\mathrm{EE}+\mathrm{CP}+\mathrm{Ash}+\mathrm{CF})$.

content $(1.80 \mathrm{~g} / \mathrm{kg}$ catechin equivalents) and low total phenolics (3.5 g/kg tannic acid equivalent). Millet ( $P$. miliaceum) originated from France. Prepressed solvent extracted cottonseed meal (Gossypium spp., bought in France) having $402 \mathrm{~g} / \mathrm{kg} \mathrm{CP}$ and $1.03 \mathrm{~g} / \mathrm{kg}$ free gossypol content was used in Experiment 1. Birds were reared in wire-floored battery cages $(83 \mathrm{~cm}$ wide $\times 52 \mathrm{~cm}$ height $\times 75 \mathrm{~cm}$ depth) in an environmentally controlled house. The environmental temperature was maintained at $32^{\circ} \mathrm{C}$ during the $1^{\text {st }}$ week and decreased to $23^{\circ} \mathrm{C}$ until the end of the experiment according to Ross guidelines (Aviagen, 2007). Experimental procedures and animal care were carried out according to French legislation at the time of the study (2013) and were approved by the local ethical committee.

\section{Experiment 1: simultaneous use of sorghum and cottonseed} meal (Experiment 1)

Four hundred and eighty six-day-old male Ross PM3 broilers were fed ad libitum from 1 to 8 days of age with a starter diet containing $12.6 \mathrm{MJ} / \mathrm{kg}$ of metabolizable energy (ME) and $225 \mathrm{~g} / \mathrm{kg}$ of CP. On day 8, birds were randomly selected and divided into nine groups. Each group contained nine replicates of six birds. Birds were assigned to replicates on the basis of BW such that homogenous BW were obtained between each replicate and treatment. The experimental period ran from 8 to 28 days of birds age. Birds were given ad libitum access to feed and water throughout the experiment.

Nine different treatments were offered in a pelleted (steam pelleting with moisture addition) form (Table 2). The control treatment (C1) was based on corn and soybean meal as the main ingredients and contained $12.3 \mathrm{MJ} / \mathrm{kg} \mathrm{ME}$ and $231 \mathrm{~g} / \mathrm{kg}$ CP. The experiment was designed with dietary level of substitution and type of ingredient as the main effects. Three experimental diets were formulated by substituting 
Batonon-Alavo, Bastianelli, Lescoat, Weber and Umar Faruk

Table 2 Dietary composition and nutrient content of experimental diets given from 8 to 28 days in Experiment 1

\begin{tabular}{|c|c|c|c|c|c|c|c|c|c|}
\hline & \multirow{2}{*}{$\frac{\text { Control }}{\mathrm{C} 1}$} & \multicolumn{3}{|c|}{ Sorghum-based diets } & \multicolumn{2}{|c|}{ Cottonseed meal-based diets } & \multicolumn{3}{|c|}{ Sorghum and cottonseed meal-based diets } \\
\hline & & S30 & S45 & S60 & CM15 & CM40 & S30/CM40 & S45/CM25 & S60/CM15 \\
\hline \multicolumn{10}{|l|}{ Ingredient (g/kg as fed) } \\
\hline Wheat & 60.0 & 60.0 & 73.1 & 80.0 & 60.0 & 60.0 & 54.6 & 71.5 & 99.2 \\
\hline Corn & 513.2 & 385.6 & 304.4 & 230.0 & 513.2 & 514.1 & 385.6 & 314.4 & 222.0 \\
\hline$S$ & - & 165.0 & 243.0 & 320.2 & - & - & 165.0 & 230.0 & 290.0 \\
\hline Soybean meal (48\%) & 365.1 & 346.0 & 340.0 & 332.0 & 307.0 & 207.9 & 206.0 & 241.0 & 275.0 \\
\hline $\mathrm{CM}$ & - & - & - & - & 55.0 & 146.0 & 130.0 & 91.2 & 58.0 \\
\hline Soybean oil & 25.0 & 7.0 & 2.0 & - & 27.0 & 30.0 & 15.0 & 10.0 & 15.0 \\
\hline Limestone & 4.0 & 4.0 & 4.0 & 4.0 & 4.0 & 3.2 & 4.0 & 4.0 & 4.0 \\
\hline Dicalcium phosphate & 23.0 & 23.0 & 23.0 & 23.0 & 22.1 & 23.5 & 24.5 & 24.0 & 24.1 \\
\hline Salt & 3.0 & 2.5 & 3.0 & 2.9 & 3.0 & 2.1 & 2.3 & 2.5 & 2.5 \\
\hline Trace mineral premix ${ }^{1}$ & 4.1 & 4.1 & 4.6 & 4.6 & 4.1 & 4.1 & 4.1 & 4.1 & 4.1 \\
\hline D,L-Methionine & 1.3 & 1.3 & 1.3 & 1.5 & 1.6 & 2.0 & 1.9 & 1.7 & 1.6 \\
\hline L-Lysine $\mathrm{HCl}$ & 1.1 & 1.3 & 1.4 & 1.6 & 2.2 & 5.0 & 5.0 & 4.1 & 3.3 \\
\hline L-Threonine & 0.2 & 0.2 & 0.2 & 0.2 & 0.8 & 2.1 & 2.0 & 1.5 & 1.2 \\
\hline \multicolumn{10}{|c|}{ Calculated composition ( $\mathrm{g} / \mathrm{kg}$ unless specified) ${ }^{2}$} \\
\hline $\mathrm{CP}$ & 215 & 216 & 217 & 218 & 216 & 218 & 218 & 218 & 219 \\
\hline Crude fat & 51.8 & 34.7 & 29.6 & 27.5 & 54.4 & 58.4 & 44.0 & 38.4 & 42.2 \\
\hline $\mathrm{Ca}$ & 9.4 & 9.3 & 9.4 & 9.4 & 9.1 & 9.0 & 9.5 & 9.4 & 9.5 \\
\hline Av. $P$ & 4.8 & 4.6 & 4.6 & 4.5 & 4.5 & 4.5 & 4.5 & 4.5 & 4.6 \\
\hline Dig Lys & 11.3 & 11.1 & 11.1 & 11.1 & 11.0 & 11.1 & 11.0 & 11.1 & 11.2 \\
\hline Dig Meth + Cyst & 7.5 & 7.4 & 7.4 & 7.5 & 7.4 & 6.9 & 6.8 & 6.9 & 7.1 \\
\hline Dig Thr & 7.5 & 7.4 & 7.4 & 7.3 & 7.4 & 7.4 & 7.4 & 7.4 & 7.5 \\
\hline Dig Trp & 2.2 & 2.2 & 2.2 & 2.2 & 1.9 & 1.5 & 1.6 & 1.8 & 2.0 \\
\hline Dig Arg & 13.4 & 13.0 & 12.9 & 12.7 & 12.2 & 10.3 & 10.1 & 10.8 & 11.5 \\
\hline Free gossypol (mg/kg) & - & - & - & - & $5.0^{3}$ & $12.0^{3}$ & 13.0 & 9.0 & 6.0 \\
\hline $\mathrm{ME}(\mathrm{MJ} / \mathrm{kg})^{4}$ & 12.3 & 12.0 & 11.9 & 11.9 & 12.5 & 12.3 & 11.9 & 11.9 & 12.1 \\
\hline \multicolumn{10}{|c|}{ Analyzed composition $(\mathrm{g} / \mathrm{kg}$ ) } \\
\hline $\mathrm{CP}$ & 231 & 224 & 222 & 227 & 226 & 217 & 219 & 215 & 215 \\
\hline Crude fat & 53.4 & 42.3 & 39.0 & 36.6 & 61.6 & 66.6 & 50.0 & 45.9 & 52.0 \\
\hline Condensed tannins & 0.47 & 0.60 & 0.63 & 0.77 & 0.66 & 0.81 & 0.89 & 0.78 & 0.68 \\
\hline NDF & 120 & 118 & 116 & 120 & 130 & 131 & 119 & 126 & 136 \\
\hline$A D F$ & 33.7 & 37.4 & 39.5 & 41.0 & 39.6 & 49.0 & 44.6 & 46.4 & 48.6 \\
\hline$A D L$ & 5.5 & 6.3 & 7.5 & 7.9 & 8.0 & 5.4 & 1.9 & 2.7 & 13.9 \\
\hline
\end{tabular}

$\mathrm{C} 1$ = control diet; $\mathrm{S}=$ sorghum; $\mathrm{CM}=$ cottonseed meal; $\mathrm{ME}=$ metabolizable energy.

The number represents the level of substitution of corn for S-based diets or soybean meal for CM-based diets.

${ }^{1}$ Premix composition (per kg): vitamin $A, 1100000 \mathrm{Ul}$; vitamin $D_{3}, 300000 \mathrm{Ul}$; vitamin $\mathrm{E}_{1}, 4000 \mathrm{Ul}$; vitamin $\mathrm{B}_{1}, 250 \mathrm{mg}$; vitamin $\mathrm{B}_{2}, 800 \mathrm{mg}$; vitamin $\mathrm{B}_{6}, 500 \mathrm{mg}$; vitamin $\mathrm{B}_{12}, 2.5 \mathrm{mg}$; vitamin PP, $5000 \mathrm{mg}$; vitamin C, 10000 mg; vitamin $\mathrm{K}_{3}, 300 \mathrm{mg} ; \mathrm{Zn}, 5400 \mathrm{mg} ; \mathrm{Cu}, 3000 \mathrm{mg} ; \mathrm{Fe}, 6000 \mathrm{mg} ; \mathrm{I}, 124 \mathrm{mg} ; \mathrm{Se}, 29.7 \mathrm{mg} ; \mathrm{Mn}, 8000 \mathrm{mg} ; \mathrm{Ca}, 0.17 \mathrm{mg} ;$ $\mathrm{Co}, 60 \mathrm{mg} ; \mathrm{Mg}, 0.08 \mathrm{~g}$; folic acid, $150 \mathrm{mg}$; choline chloride, $50004 \mathrm{mg}$; biotin, $15 \mathrm{mcg}$. Premix also supplied titanium $1.0 \mathrm{~g} / \mathrm{kg}$ of diet and Avatec, $0.6 \mathrm{~g} / \mathrm{kg}$ of diet.

${ }^{2}$ Nutritional values were calculated, based on Sauvant et al. (2004).

${ }^{3}$ Analyzed composition.

${ }^{4} \mathrm{ME}$ content estimated using European energy equation (Fisher and McNab, 1987).

$30 \%, 45 \%$ or $60 \%$ of the corn by sorghum (S) and two other diets were similarly formulated by replacing $15 \%$ or $40 \%$ of the soybean meal with cottonseed meal (CM). To test the effect of simultaneous inclusion of both $\mathrm{S}$ and $\mathrm{CM}$, three other diets combined the level of substitution of sorghum and cottonseed meal as follows: $30 \% \mathrm{~S}$ and $40 \% \mathrm{CM}$, $45 \% \mathrm{~S}$ and $25 \% \mathrm{CM} ; 60 \% \mathrm{~S}$ and $15 \% \mathrm{CM}$. Diets were formulated to meet Ross broiler nutrient specifications (Aviagen, 2007) and included $1 \mathrm{~g} / \mathrm{kg}$ titanium dioxide $\left(\mathrm{TiO}_{2}\right)$ as digestibility marker. All diets were formulated to be isocaloric and isonitrogenous by adjusting soybean oil, wheat and amino acids supply to avoid any essential amino acids as limiting factor.
Experiment 2: total corn substitution by millet and sorghum in broiler diets (Experiment 2)

Four hundred and eighty six-day-old male Ross PM3 broilers were fed ad libitum with the same starter feed as in Experiment 1 from 1 to 8 days. On day 8 , nine replicates (of six chicks per cage) of similar BW were constituted per treatment. The experimental period ran from 8 to 27 days of age. Birds were given one of the 10 treatments: a control (C2) complete feed and nine experimental diets designed as a factorial arrangement $(3 \times 3)$ with dietary level of substitution and type of ingredient as the main effects (Table 3). All diets were fed as pellets.

The aim of this experiment was to establish whether it would be possible to substitute corn with sorghum beyond 
Sorghum, millet and cottonseed meal in broilers

Table 3 Dietary composition and nutrient content of experimental diets given from 8 to 27 days in Experiment 2

\begin{tabular}{|c|c|c|c|c|c|c|c|c|c|c|}
\hline & \multirow{2}{*}{$\frac{\text { Control }}{\mathrm{C} 2}$} & \multicolumn{3}{|c|}{ Sorghum-based diets } & \multicolumn{3}{|c|}{ Millet-based diets } & \multicolumn{3}{|c|}{ Sorghum and millet-based diets } \\
\hline & & $S 60$ & S80 & S100 & M60 & M80 & M100 & S30/M30 & S40/M40 & S50/M50 \\
\hline \multicolumn{11}{|l|}{ Ingredient ( $\mathrm{g} / \mathrm{kg}$ as fed) } \\
\hline Wheat & 61.8 & 50.0 & 60.4 & 71.0 & 70.1 & 75.9 & 105.2 & 68.8 & 66.2 & 106.7 \\
\hline Corn & 500.7 & 213.6 & 120.0 & - & 220.0 & 120.0 & - & 220.0 & 129.2 & - \\
\hline$S$ & - & 310.0 & 400.7 & 514.0 & - & - & - & 150.0 & 200.5 & 250.2 \\
\hline Soybean meal (48\%) & 375.0 & 357.9 & 354.4 & 349.5 & 334.0 & 318.0 & 300.0 & 347.7 & 338.3 & 325.9 \\
\hline M & - & - & - & - & 310.7 & 420.1 & 528.2 & 150.0 & 200.5 & 250.2 \\
\hline Soybean oil & 28.0 & 30.0 & 30.0 & 30.0 & 30.0 & 30.0 & 30.0 & 29.0 & 30.0 & 30.8 \\
\hline Limestone & 3.7 & 3.3 & 3.1 & 3.5 & 3.7 & 5.2 & 5.4 & 3.9 & 4.0 & 4.2 \\
\hline Dicalcium phosphate & 21.3 & 22.7 & 22.9 & 23.2 & 22.2 & 20.8 & 20.5 & 21.7 & 22.0 & 22.0 \\
\hline Salt & 3.3 & 2.7 & 2.5 & 2.5 & 3.0 & 2.9 & 2.8 & 2.8 & 2.9 & 2.8 \\
\hline Trace mineral premix ${ }^{1}$ & 4.6 & 4.1 & 4.1 & 4.1 & 4.1 & 4.1 & 4.1 & 4.1 & 4.1 & 4.1 \\
\hline$D, L-M e t h i o n i n e$ & 1.2 & 4.0 & 1.1 & 1.2 & 1.1 & 1.2 & 1.3 & 1.2 & 1.2 & 1.3 \\
\hline L-Lysine $\mathrm{HCl}$ & 0.4 & 0.7 & 0.8 & 1.0 & 1.1 & 1.6 & 2.1 & 0.8 & 1.1 & 1.6 \\
\hline L-Threonine & - & 1.0 & - & - & - & 0.2 & 0.4 & - & - & 0.2 \\
\hline \multicolumn{11}{|c|}{ Calculated composition (g/kg unless specified) ${ }^{2}$} \\
\hline $\mathrm{CP}$ & 219 & 219 & 217 & 218 & 218 & 218 & 218 & 218 & 218 & 218 \\
\hline Crude fat & 63.2 & 61.3 & 59.7 & 57.6 & 64.1 & 63.6 & 62.0 & 61.5 & 61.8 & 59.8 \\
\hline $\mathrm{Ca}$ & 9.0 & 9.0 & 9.0 & 9.1 & 9.0 & 9.2 & 9.1 & 9.0 & 9.1 & 9.1 \\
\hline Av. $P$ & 4.5 & 4.5 & 4.5 & 4.50 & 4.70 & 4.5 & 4.5 & 4.50 & 4.50 & 4.5 \\
\hline Dig Lys & 11.5 & 11.1 & 11.0 & 11.0 & 11.1 & 11.1 & 11.0 & 11.0 & 11.0 & 11.1 \\
\hline Dig Meth + Cyst & 7.9 & 10.0 & 7.3 & 7.3 & 7.3 & 7.1 & 7.0 & 7.5 & 7.4 & 7.3 \\
\hline Dig Thr & 7.9 & 8.5 & 7.5 & 7.4 & 7.4 & 7.4 & 7.4 & 7.5 & 7.4 & 7.4 \\
\hline Dig Trp & 2.4 & 2.3 & 2.4 & 2.4 & 2.5 & 2.6 & 2.6 & 2.4 & 2.5 & 2.5 \\
\hline Dig Arg & 14.2 & 13.1 & 12.6 & 12.2 & 13.5 & 13.4 & 13.2 & 13.1 & 13.3 & 12.7 \\
\hline $\mathrm{ME}(\mathrm{MJ} / \mathrm{kg})^{3}$ & 12.5 & 12.6 & 12.5 & 12.6 & 12.8 & 12.8 & 12.8 & 13.0 & 12.5 & 12.8 \\
\hline \multicolumn{11}{|c|}{ Analyzed composition (g/kg) } \\
\hline $\mathrm{CP}$ & 224 & 226 & 219 & 224 & 226 & 221 & 220 & 224 & 223 & 218 \\
\hline Crude fat & 57.7 & 60.7 & 60.1 & 61.2 & 66.4 & 70.4 & 72.7 & 72.8 & 62.9 & 74.5 \\
\hline Condensed tannins & - & 0.60 & 0.54 & 0.78 & - & - & - & 0.31 & 0.40 & 0.43 \\
\hline NDF & 76.8 & 90.0 & 81.7 & 81.4 & 91.3 & 101.0 & 111.8 & 91.9 & 95.3 & 95.2 \\
\hline$A D F$ & 30.2 & 32.1 & 32.1 & 33.7 & 38.3 & 44.6 & 50.0 & 36.7 & 39.5 & 39.8 \\
\hline NDL & 4.7 & 5.1 & 5.6 & 6.1 & 4.8 & 5.8 & 7.7 & 5.4 & 5.1 & 3.4 \\
\hline
\end{tabular}

$\mathrm{C} 2$ = control diet; $\mathrm{S}=$ sorghum; $\mathrm{M}=$ millet; $\mathrm{ME}=$ metabolizable energy.

The number represents the level of substitution of corn.

${ }^{1}$ Premix composition (per kg): vitamin $A, 1100000$ Ul; vitamin $D_{3}, 300000$ Ul; vitamin $E_{1} 4000$ Ul; vitamin $B_{1}, 250$ mg; vitamin $B_{2}, 800$ mg; vitamin $B_{6}, 500$ mg; vitamin $\mathrm{B}_{12}$, $2.5 \mathrm{mg}$; vitamin PP, 5000 mg; vitamin C, 10000 mg; vitamin K 300 mg; Zn, 5400 mg; Cu, 3000 mg; Fe, 6000 mg; l, 124 mg; Se, 29.7 mg; Mn, 8000 mg; Ca, 0.17 mg; Co, $60 \mathrm{mg}$; Mg, $0.08 \mathrm{~g}$; folic acid, $150 \mathrm{mg}$; choline chloride, $50004 \mathrm{mg}$; biotin, $15 \mathrm{mcg}$. Premix also supplied titanium $1.0 \mathrm{~g} / \mathrm{kg}$ of diet and Avatec, $0.6 \mathrm{~g} / \mathrm{kg}$ of diet.

${ }^{2}$ Nutritional values were calculated, based on Sauvant et al. (2004).

${ }^{3} \mathrm{ME}$ content estimated using European energy equation (Fisher and McNab, 1987).

the levels of substitution used in Experiment 1. Therefore, three other experimental diets were formulated by replacing $60 \%, 80 \%$ or $100 \%$ of the corn with sorghum $(\$ 60,580$ and S100). Three millet-based diets (M60, M80 and M100) were formulated in the same way. In order to assess the interactions that might exist when these ingredients are used simultaneously, three other diets were formulated by substituting different proportions of the corn with both $\mathrm{S}$ and $\mathrm{M}$ (S30/M30, S40/M40, S50/M50). Birds were given ad libitum access to feed and water throughout the experiment. All diets were formulated to be isocaloric $(12.69 \pm 0.05 \mathrm{MJ} / \mathrm{kg})$ and isonitrogenous $(222.5 \pm 0.9 \mathrm{~g} / \mathrm{kg})$ and formulated to meet Ross broiler nutrient specifications (Aviagen, 2007) as in Experiment1. $\mathrm{TiO}_{2}$ was included at $1 \mathrm{~g} / \mathrm{kg}$ in all diets as digestibility marker.

\section{Measurements}

Performance (Experiments 1 and 2). Chicken BW was measured at days 8, 15, 21 and 28 in Experiment 1. In Experiment 2, birds were weighed at days 8, 14 and 27. Feed intake was measured every week by weighing feed refusals in all experiments. Due to practical reasons, feed intake and BW were not measured at day 20 in Experiment 2. Feed conversion ratio (FCR) was calculated as the ratio between total feed intake and BW gain of all birds in each cage. Feed intake, BW gain and FCR were calculated after correcting for mortalities.

Apparent ileal digestibility (AID) (Experiments 1 and 2). At the end of each experimental period, all birds were slaughtered by cervical dislocation. The contents of the terminal part of the ileum, defined as the region between 17 and $2 \mathrm{~cm}$ 
proximal to the ileocaecal junction were collected for ileal digestibility determinations. Digesta of birds were pooled per cage, freeze-dried and ground before analysis. All digesta samples were analyzed for dry matter (DM), nitrogen and concentration of titanium as indigestible marker. The AID coefficient of nutrients in the two experiments was calculated according to the following equation:

$$
\text { AID }(\%)=\left\{1-\left(\frac{\mathrm{Ti}_{\text {Diet }}}{\mathrm{Ti}_{\text {ileum }}} \times \frac{\text { Nutrient }_{\text {ileum }}}{\text { Nutrient }_{\text {Diet }}}\right)\right\} \times 100
$$

where $\mathrm{Ti}_{\text {Diet }}$ and $\mathrm{Ti}_{\mathrm{ileum}}$ represent concentration of titanium in feed and ileal digesta, respectively. Nutrient ${ }_{\text {Diet }}$ and Nutrient $_{\text {ileum }}$ are the nutrients (protein and energy) in feed and ileal digesta.

Total tract digestibility (Experiment 2). In the second experiment, plastic trays were placed under cages for total excreta collection. Representative samples of excreta were then collected from six cages per treatment over a period of $3 \times 24 \mathrm{~h}$ from day 22 to 24 . All excreta samples were freeze-dried and then ground to pass through $0.5 \mathrm{~mm}$ sieve. Samples of diets and excreta were analyzed for DM, gross energy (GE), starch, fat, total $\mathrm{N}$ and protein N. Apparent metabolizable energy (AME) was calculated as the difference between energy intake and excretion, relative to feed intake. AME was then corrected for the energy of $\mathrm{N}$ retention (AMEn) according to Hill and Anderson (1958).

\section{Chemical analysis}

Chemical composition of feeds and faeces was determined following standard procedures (AOAC International, 1995). DM was determined with oven drying at $103^{\circ} \mathrm{C}$. Crude fat contents were determined after a saponification with determination by gas chromatography (Büchi, B820). GE was determined using a bomb calorimeter (C2000 Basic; IKA, Germany). Total nitrogen analysis was carried out with a Leco $\mathrm{N}$ analyzer (LECO, FP528) and $C P$ was then calculated as $N \times 6.25$. Starch was measured using a polarimeter (ADP 410; Bellingham and Stanley, UK). Total sugars were determined according to Luff-Schoorl method. NDF, ADF and ADL in feed ingredients and diets were measured on Fibertech according to Van Soest and Wine (1967). Titanium concentrations were determined by Induction Coupled Plasma after $\mathrm{HNO}_{3} / \mathrm{NH}_{4} \mathrm{~F}$ mineralization in microwaves. Total tract protein nitrogen (Terpstra and de Hart, 1974) and total tract starch were determined by Near Infrared Spectroscopy (NIRS) according to Bastianelli et al. (2010). Condensed tannins were determined by vanillin assay and expressed as catechin equivalent. Gossypol contents were determined by colorimetry following the standard ISO6866.

\footnotetext{
Statistical analysis

Data analyses were performed using $R$ version 3.0.2 (R Core Team, 2013).

The mortality recorded for all treatments in each experiment was submitted to a one-way ANOVA. In Experiment 1, data collected was analyzed based on three periods: (1) 8 to
}

15 days; (2) 15 to 21 days (3) 21 to 27 days. In Experiment 2, analyses were performed based on two periods: (1) 8 to 14 days and (2) 14 to 27 days. A one-way ANOVA was performed in each period of age to test the treatment effect (nine levels in Experiment 1; 10 levels in Experiment 2) on feed intake, weight gain and FCR. Data were also submitted to a one-way ANOVA to evaluate the effect of the type of ingredient irrespective of its level: C1 v. S v. CM v. S/CM in Experiment 1 and $C 2$ v. S v. M v. S/M in Experiment 2. To assess the effect of the level of substitution, treatments of each ingredient were submitted to a Kruskal-Wallis test at each period of age. These analyses were also realized on the data collected for AID and total tract digestibility.

Tested factors were considered significant if $P<0.001$, $P<0.01$ and $P<0.05$, discussed as a trend if $P<0.10$, and not significant if $P>0.10$. A Bonferroni-Dunnet pairwise comparison was used to compare differences between mean after each ANOVA test being performed. A multiple comparisons post hoc test (Siegel and Castellan, 1988) was realized to compare differences between means for the level of substitution effect in each ingredient-based diets.

\section{Results}

Experiment 1: simultaneous use of sorghum and cottonseed meal

Performance. The overall mortality from 8 to 28 days was $4.17 \pm 0.91 \%$ and was not influenced by the treatments.

Feed intake was not affected by treatments throughout the experimental period (Table 4). However, from 21 to 28 days and 8 to 28 days, it tended to be influenced by the type of ingredient with the lowest values in $\mathrm{CM}$-based diets and the highest in $\mathrm{S}$-based diets $(P=0.07)$. Feed intake of the control diet and S/CM-based diets were intermediate. There was no significant effect of the level of substitution of each ingredient on feed intake.

Weight gain was similar among treatments and was not affected by the inclusion of sorghum or cottonseed meal. A high weight gain value $(82.7 \mathrm{~g} / \mathrm{b}$ per day) was recorded for S30 diet at days 15 to 21 . This induced a trend for a level effect in sorghum at this period.

CM-based diets resulted in a similar FCR to control diet (1.49 v. 1.50). Higher FCR were obtained with sorghum- (1.55) and S/ CM-based diets (1.54). The lowest FCR value was observed with CM15 (1.47) while the highest was obtained with S45/ CM25 (1.58). However, only a few significant differences of FCR were obtained in the first two periods regarding the doseresponse effect of each ingredient. FCR increased with the level of substitution of $S$ and $\mathrm{CM}$. When the two ingredients were included in the same diet from 8 to 15 days, FCR was affected due to a low value in S60/CM15.

AID of protein and energy. Table 5 shows the effect of treatments on AID of protein and energy. AID of protein of all experimental treatments was lower to control diet $(82.93 \pm 0.70 \%)$. This difference was not significant for diets 
Table 4 Effect of diets with sorghum (S), cottonseed meal (CM) or their combination (S/CM) on the performance of broilers fed from 8 to 28 days old (Experiment 1)

\begin{tabular}{|c|c|c|c|c|c|c|c|c|c|c|c|c|}
\hline \multirow[b]{2}{*}{ Age (days) } & \multicolumn{4}{|c|}{ Feed intake (g/b per day) } & \multicolumn{4}{|c|}{ Weight gain (g/b per day) } & \multicolumn{4}{|c|}{ FCR } \\
\hline & 8 to -15 days & 15 to 21 days & 21 to 28 days & 8 to 28 days & 8 to 15 days & 15 to 21 days & 21 to 28 days & 8 to 28 days & 8 to 15 days & 15 to 21 days & 21 to 28 days & 8 to 28 days \\
\hline $\mathrm{C} 1$ & 64.1 & 115 & 151 & 111 & 50.3 & 80.8 & 89.2 & 74.2 & $1.27^{\mathrm{a}}$ & $1.43^{\mathrm{a}}$ & 1.70 & $1.50^{\mathrm{ba}}$ \\
\hline S30 & 67.0 & 121 & 156 & 115 & 49.8 & 82.7 & 90.0 & 74.1 & $1.35^{\mathrm{ab}}$ & $1.46^{\mathrm{a}}$ & 1.73 & $1.55^{\mathrm{bc}}$ \\
\hline S45 & 65.1 & 118 & 161 & 115 & 48.7 & 78.2 & 95.1 & 74.0 & $1.33^{\mathrm{ab}}$ & $1.50^{\mathrm{a}}$ & 1.70 & $1.55^{\mathrm{b}}$ \\
\hline S60 & 66.8 & 124 & 160 & 117 & 49.8 & 79.1 & 94.3 & 74.4 & $1.34^{\mathrm{ab}}$ & $1.57^{\mathrm{b}}$ & 1.69 & $1.57^{\mathrm{b}}$ \\
\hline CM15 & 65.0 & 113 & 148 & 109 & 50.2 & 81.1 & 90.0 & 73.8 & $1.29^{\mathrm{ab}}$ & $1.40^{\mathrm{a}}$ & 1.65 & $1.47^{\mathrm{a}}$ \\
\hline CM40 & 65.2 & 119 & 153 & 112 & 49.5 & 79.6 & 94.6 & 74.6 & $1.32^{\mathrm{ab}}$ & $1.49^{\mathrm{ab}}$ & 1.62 & $1.51^{\mathrm{ba}}$ \\
\hline S30/CM40 & 67.3 & 114 & 157 & 112 & 49.2 & 78.8 & 92.5 & 73.5 & $1.37^{\mathrm{ab}}$ & $1.44^{\mathrm{a}}$ & 1.72 & $1.53^{b}$ \\
\hline S45/CM25 & 67.4 & 115 & 159 & 114 & 48.6 & 79.6 & 89.9 & 72.6 & $1.38^{\mathrm{b}}$ & $1.51^{\mathrm{a}}$ & 1.78 & $1.58^{\mathrm{c}}$ \\
\hline S60/CM15 & 65.9 & 118 & 154 & 113 & 50.1 & 80.2 & 92.7 & 74.3 & $1.31^{\mathrm{ab}}$ & $1.48^{\mathrm{a}}$ & 1.67 & $1.52^{\text {ba }}$ \\
\hline SEM & 1.3 & 3 & 4 & 2 & 0.7 & 2.1 & 2.7 & 1.2 & 0.02 & 0.03 & 0.03 & 0.01 \\
\hline Treatment effect $^{1}$ & ns & ns & ns & ns & ns & ns & ns & ns & * & ** & ns & $* * *$ \\
\hline $\begin{array}{l}\text { Type of ingredient }{ }^{2} \\
\text { Level of substitution }\end{array}$ & ns & ns & $\dagger$ & $\dagger$ & ns & ns & ns & ns & ** & * & ns & $* * *$ \\
\hline$S$ & ns & ns & ns & ns & ns & $\dagger$ & ns & ns & ns & * & ns & ns \\
\hline $\mathrm{CM}$ & ns & ns & ns & ns & ns & ns & ns & ns & * & $* *$ & ns & ns \\
\hline $\mathrm{S}$ and $\mathrm{CM}$ & ns & ns & ns & ns & ns & ns & ns & ns & $* *$ & ns & ns & ns \\
\hline
\end{tabular}

C1 = control diet; FCR = feed conversion ratio.

The number represents the level of substitution of corn for S-based diets or soybean meal for CM-based diets.

'Effect of treatments: ANOVA on nine diets.

Effect of the type of ingredient: ANOVA on four treatments (control v. S-based diets v. CM-based diets v. S/CM-based diets).

Effect of the level of substitution (dose-response effect) within each type of ingredient.

a,b, Values with the same superscript are not significantly different at $P<0.05$

${ }^{* * *} P<0.001 ;{ }^{* *} P<0.01 ;{ }^{*} P<0.05 ;+P \leqslant 0.10$. ns: not significant at $P>0.10$ 
Table 5 Apparent ileal digestibility of protein and energy of broilers fed sorghum- (S) and/or cottonseed meal- (CM) based diets measured at 28 days (Experiment 1)

\begin{tabular}{|c|c|c|}
\hline & AID of protein $(\%)$ & AID of energy (\%) \\
\hline $\mathrm{C1}$ & $82.9^{\mathrm{a}}$ & $78.1^{\mathrm{a}}$ \\
\hline S30 & $81.3^{\mathrm{a}}$ & $77.1^{\mathrm{ac}}$ \\
\hline S45 & $80.5^{\mathrm{ab}}$ & $76.2^{\mathrm{ac}}$ \\
\hline S60 & $80.3^{\mathrm{ab}}$ & $75.1^{\text {bcd }}$ \\
\hline CM15 & $79.6^{\mathrm{ab}}$ & $75.7^{\mathrm{ab}}$ \\
\hline CM40 & $78.0^{b c}$ & $72.7^{\text {de }}$ \\
\hline S30/CM40 & $74.7^{c}$ & $70.2^{\mathrm{e}}$ \\
\hline S45/CM25 & $78.0^{b}$ & $73.3^{\text {bd }}$ \\
\hline S60/CM15 & $77.4^{\mathrm{bc}}$ & $72.7^{\text {de }}$ \\
\hline SEM & 0.77 & 0.60 \\
\hline General treatment effect ${ }^{1}$ & $* * *$ & $* * *$ \\
\hline $\mathrm{C}$ v. S v. CM v. S/CM ${ }^{2}$ & $* * *$ & $* * *$ \\
\hline \multicolumn{3}{|l|}{ Level of substitution ${ }^{3}$} \\
\hline$S$ & ns & $\dagger$ \\
\hline $\mathrm{CM}$ & ns & *** \\
\hline $\mathrm{S}$ and $\mathrm{CM}$ & * & * \\
\hline
\end{tabular}

$\mathrm{C} 1$ = control diet; AID = apparent ileal digestibility.

The number represents the level of substitution of corn for S-based diets or soybean meal for CM-based diets.

${ }^{1}$ Effect of treatments: ANOVA on nine diets.

${ }^{2}$ Effect of the type of ingredient: ANOVA on four treatments (control $v$. S-based diets v. CM-based diets v. S/CM-based diets).

${ }^{3}$ Effect of the level of substitution (dose-response effect) within each type of ingredient.

$a, b, c, d, e$ Values with the same superscript are not significantly different at $P<0.05$.

${ }^{* *} P<0.001 ;{ }^{*} P<0.01 ;{ }^{*} P<0.05 ; \dagger P \leqslant 0.10$. ns: not significant at $P>0.10$. based on sorghum $(80.69 \pm 0.34 \%)$, but it was significant for CM-based diets $(78.81 \pm 0.59 \%)$. AID of protein of S/CM-based diets was the lowest $(76.71 \pm 0.55 \%)$, with values significantly lower from control and S-based diets. No effect of the level of substitution was found on AID of protein in S- and CM-based diets. However, the combination of these two ingredients affected AID of protein in relation to the low value in $\mathrm{S} 30 / \mathrm{CM} 40$.

AID of energy was different among treatments with the highest values in control $(78.11 \pm 0.66 \%)$ and the lowest in $\mathrm{S} /$ CM-based diets $(72.05 \pm 0.52 \%)$. AID of energy obtained with S-based diets $(76.12 \pm 0.31 \%)$ was not significantly different from the control whereas in CM-based diets $(74.19 \pm 0.51 \%)$ it was lower than the control. The level of substitution of sorghum tended to affect AID of energy $(P=0.09)$ while in CM-based diets, AID of energy decreased with the increasing level of substitution. Combination of sorghum and cottonseed meal affected AID of energy with the lowest values in S30/CM40 diet and the highest in S45/CM25 diet.

\section{Experiment 2: total corn substitution by millet and sorghum in broiler diets}

Performance. The overall mortality recorded in this experiment was $2.41 \pm 0.62 \%$ and was not affected by the treatments.

Simultaneous utilization of sorghum and millet resulted in similar feed intake and growth performance as the control diet (Table 6). As main effects, sorghum and millet did not have a significant impact on feed intake, weight gain and FCR.

Table 6 Effect of diets with sorghum (S), millet (M) or their combination (S/M) on the performance of broilers fed from 8 to 27 days old (Experiment 2)

\begin{tabular}{|c|c|c|c|c|c|c|c|c|c|}
\hline & \multicolumn{3}{|c|}{ Feed intake (g/b per day) } & \multicolumn{3}{|c|}{ Weight gain (g/b per day) } & \multicolumn{3}{|c|}{ FCR } \\
\hline & 8 to 14 days & 15 to 20 days & 8 to 27 days & 8 to 14 days & 15 to 27 days & 8 to 27 days & 8 to 14 days & 15 to 20 days & 8 to 27 days \\
\hline $\mathrm{C} 2$ & 62.7 & 134 & 109 & 47.3 & 84.6 & 71.6 & 1.33 & 1.58 & 1.52 \\
\hline S60 & 61.6 & 131 & 107 & 45.9 & 85.3 & 71.5 & 1.34 & 1.54 & 1.50 \\
\hline S80 & 61.9 & 132 & 108 & 45.8 & 85.8 & 71.8 & 1.35 & 1.54 & 1.50 \\
\hline $\mathbf{S 1 0 0}$ & 63.9 & 132 & 108 & 47.6 & 82.8 & 70.4 & 1.34 & 1.60 & 1.54 \\
\hline M60 & 63.6 & 130 & 107 & 46.4 & 85.9 & 72.1 & 1.37 & 1.51 & 1.48 \\
\hline M80 & 62.1 & 134 & 109 & 44.8 & 86.5 & 71.9 & 1.38 & 1.55 & 1.51 \\
\hline M100 & 62.4 & 132 & 108 & 46.4 & 85.0 & 71.5 & 1.35 & 1.55 & 1.51 \\
\hline S30/M30 & 59.8 & 128 & 104 & 45.3 & 81.7 & 68.9 & 1.32 & 1.56 & 1.51 \\
\hline S40/M40 & 63.1 & 132 & 108 & 45.0 & 84.6 & 71.2 & 1.42 & 1.55 & 1.52 \\
\hline S50/M50 & 63.3 & 133 & 109 & 48.2 & 84.2 & 71.6 & 1.34 & 1.58 & 1.52 \\
\hline SEM & 1.5 & 2.0 & 1.5 & 1.3 & 1.6 & 1.2 & 0.02 & 0.02 & 0.02 \\
\hline Treatment effect $^{1}$ & ns & ns & ns & ns & ns & ns & ns & ns & ns \\
\hline $\begin{array}{l}\text { Type of ingredient }{ }^{2} \\
\text { Level of substitution }^{3}\end{array}$ & ns & ns & ns & ns & ns & ns & ns & ns & ns \\
\hline $\mathrm{S}$ & ns & ns & ns & ns & ns & ns & * & ns & ns \\
\hline $\mathrm{M}$ & ns & ns & ns & ns & ns & ns & ns & ns & ns \\
\hline $\mathrm{S}$ and $\mathrm{M}$ & ns & ns & ns & ns & ns & ns & ns & ns & ns \\
\hline
\end{tabular}

$\mathrm{C} 2$ = control diet; FCR $=$ feed conversion ratio.

The number represents the level of substitution of corn.

${ }^{1}$ Effect of treatments: ANOVA on 10 diets.

${ }^{2}$ Effect of the type of ingredient: ANOVA on four treatments (control v. S-based diets v. M-based diets v. S/M-based diets).

${ }^{3}$ Effect of the level of substitution (dose-response effect) within each type of ingredient.

${ }^{*} P<0.05$; ns: not significant at $P>0.10$. 
Table 7 Apparent ileal digestibility of protein and energy of broilers fed sorghum- (S) and/or millet- (M) based diets measured at 27 days (Experiment 2)

\begin{tabular}{|c|c|c|}
\hline & AID of protein (\%) & AID of energy (\%) \\
\hline $\mathrm{C} 2$ & $80.4^{\mathrm{ac}}$ & $74.6^{\mathrm{a}}$ \\
\hline S60 & $82.8^{\mathrm{abc}}$ & $75.9^{\mathrm{ab}}$ \\
\hline S80 & $81.3^{\mathrm{abc}}$ & $74.6^{\mathrm{a}}$ \\
\hline S100 & $82.4^{\mathrm{abc}}$ & $76.3^{\mathrm{ab}}$ \\
\hline M60 & $84.3^{b}$ & $78.4^{\mathrm{b}}$ \\
\hline M80 & $84.2^{\mathrm{b}}$ & $77.9^{b}$ \\
\hline M100 & $82.6^{a b c}$ & $75.9^{\mathrm{ab}}$ \\
\hline S30/M30 & $83.2^{\mathrm{abc}}$ & $77.0^{\mathrm{ab}}$ \\
\hline S40/M40 & $83.7^{\mathrm{ab}}$ & $77.7^{\mathrm{b}}$ \\
\hline S50/M50 & $79.5^{c}$ & $74.6^{\mathrm{a}}$ \\
\hline SEM & 0.69 & 0.54 \\
\hline Treatment effect $^{1}$ & $* * *$ & $* * *$ \\
\hline Type of ingredient ${ }^{2}$ & $* *$ & ** \\
\hline \multicolumn{3}{|l|}{ Level of substitution ${ }^{3}$} \\
\hline$S$ & ns & $t$ \\
\hline$M$ & ** & ** \\
\hline $\mathrm{S}$ and $\mathrm{M}$ & ** & * \\
\hline
\end{tabular}

$\mathrm{C} 2$ = control diet; AID = apparent ileal digestibility.

The number represents the level of substitution of corn.

${ }^{1}$ Effect of treatments: ANOVA on 10 diets.

${ }^{2}$ Effect of the type of ingredient: ANOVA on four treatments (control $v$. S-based diets $v$. M-based diets v. S/M-based diets).

${ }^{3}$ Effect of the level of substitution (dose-response effect) within each type of ingredient.

${ }_{a, b, c}$ Values with the same superscript are not significantly different at $P<0.05$. ${ }^{* * *} P<0.001 ;{ }^{* *} P<0.01 ;{ }^{*} P<0.05 ; \dagger P \leqslant 0.10$. ns: not significant at $P>0.10$.

No difference of level of substitution of the feed ingredient was observed for M-based diets and S/M-based diets. However, there was a significant difference between the three $\mathrm{S}$-based diets from 8 to 14 days of age with no significant post hoc effect.

AID of protein and energy. The effects of the type of cereal on AID of protein and energy are shown in Table 7. AID of protein of all experimental treatments was higher than the control diet $(80.40 \pm 1.44 \%)$. This difference was not significant for S- $(82.17 \pm 0.44 \%)$ and S/M-based diets $(82.15 \pm 0.60 \%)$. However, it was significant for millet-based diets $(83.73 \pm 0.23 \%)$. AID of protein was affected with the increasing level of millet when it was used separately or combined with sorghum. However, no significant difference was found between these diets with the post hoc test. No dose-response effect of sorghum was found on AID of protein.

Similar results were obtained for the AID of energy with the highest values in $M-$, followed by S/M-, S-based and control diets in descending order. The level of substitution tended to affect AID of energy in S-based diets $(P=0.09)$ while it significantly affected AID of energy in M-based diets and S/M-based diets.

Total tract digestibility of DM, protein, fat and starch and AMEn values. Total tract digestibility of nutrients is shown in Table 8. There were significant differences in DM digestibility, although none of the experimental treatments
Table 8 Total tract nutrient digestibility and nitrogen-corrected apparent metabolizable energy (AMEn; MJ/kg DM) of S- and/or $M$-based diets of broilers measured on faeces collected from 22 to 24 days (Experiment 2)

\begin{tabular}{|c|c|c|c|c|c|}
\hline & \multicolumn{4}{|c|}{ Nutrient digestibility (\%) } & \multirow{2}{*}{$\begin{array}{l}\text { AMEn (MJ/kc } \\
\text { DM) }\end{array}$} \\
\hline & DM & Protein & Fat & Starch & \\
\hline $\mathrm{C} 2$ & $68.8^{\mathrm{abc}}$ & $81.5^{\mathrm{a}}$ & $82.2^{\mathrm{abc}}$ & $97.2^{\mathrm{ab}}$ & $13.3^{\mathrm{ab}}$ \\
\hline S60 & $68.1^{\mathrm{abc}}$ & $80.5^{\mathrm{ab}}$ & $79.2^{\mathrm{a}}$ & $96.4^{\mathrm{abc}}$ & $13.2^{\mathrm{ab}}$ \\
\hline S80 & $67.5^{b c}$ & $78.9^{\mathrm{ab}}$ & $80.1^{\mathrm{ab}}$ & $95.7^{\text {cd }}$ & $13.1^{\mathrm{ab}}$ \\
\hline S100 & $66.9^{c}$ & $78.7^{\mathrm{abc}}$ & $80.2^{\mathrm{ab}}$ & $94.9^{d}$ & $13.0^{\mathrm{b}}$ \\
\hline M60 & $69.3^{\mathrm{ab}}$ & $78.7^{\mathrm{ab}}$ & $82.7^{\mathrm{abc}}$ & $97.6^{\mathrm{a}}$ & $13.4^{\mathrm{a}}$ \\
\hline M80 & $69.3^{a b}$ & $77.6^{\mathrm{abc}}$ & $83.2^{\mathrm{abc}}$ & $96.9^{\text {ae }}$ & $13.4^{\mathrm{a}}$ \\
\hline M100 & $68.8^{\mathrm{abc}}$ & $75.0^{c}$ & $84.0^{\mathrm{bc}}$ & $97.0^{\text {abe }}$ & $13.3^{\mathrm{ab}}$ \\
\hline S30/M30 & $69.5^{a}$ & $79.4^{\mathrm{ab}}$ & $86.1^{c}$ & $96.8^{\mathrm{ae}}$ & $13.4^{\mathrm{a}}$ \\
\hline S40/M40 & $68.4^{\mathrm{abc}}$ & $77.3^{\mathrm{bc}}$ & $82.1^{\mathrm{abc}}$ & $96.1^{\text {bce }}$ & $13.3^{\mathrm{ab}}$ \\
\hline S50/M50 & $67.8^{\mathrm{abc}}$ & $77.0^{\mathrm{bc}}$ & $83.4^{\mathrm{abc}}$ & $95.8^{\mathrm{de}}$ & $13.2^{\mathrm{ab}}$ \\
\hline SEM & 0.38 & 0.75 & 0.87 & 0.24 & 0.07 \\
\hline Treatment effect $^{1}$ & $* * *$ & $* * *$ & $* * *$ & $* * *$ & $* * *$ \\
\hline $\begin{array}{l}\text { Type of } \\
\text { ingredient }^{2}\end{array}$ & $* * *$ & $* * *$ & *** & $* * *$ & ** \\
\hline \multicolumn{6}{|c|}{ Level of substitution ${ }^{3}$} \\
\hline$S$ & * & $\dagger$ & ns & * & $\dagger$ \\
\hline$M$ & ns & $\dagger$ & ns & $\dagger$ & ns \\
\hline $\mathrm{S}$ and $\mathrm{M}$ & ^ & ns & ** & * & ns \\
\hline
\end{tabular}

$\mathrm{C} 2=$ control diet; $\mathrm{S}=$ sorghum; $\mathrm{M}=$ millet; $\mathrm{DM}=$ dry matter.

The number represents the level of substitution of corn.

${ }^{1}$ Effect of treatments: ANOVA on 10 diets.

${ }^{2}$ Effect of the type of ingredient: ANOVA on four treatments (control $v$. S-based diets v. M-based diets v. S/M-based diets).

${ }^{3}$ Effect of the level of substitution (dose-response effect) within each type of ingredient.

$a, b, c, d, e$ Values with the same superscript are not significantly different at $P<0.05$.

${ }^{* * *} P<0.001 ;{ }^{* *} P<0.01 ;{ }^{*} P<0.05 ;+P \leqslant 0.10$. ns: not significant at $P>0.10$.

was significantly different from the control diet $(68.81 \pm$ $0.46 \%$ ). Lower DM digestibility was observed with S-based diets $(67.52 \pm 0.17 \%)$ compared with M-based diets $(69.15 \pm 0.30 \%)$. S/M-based diets were intermediate $(68.57 \pm 0.25 \%)$. In $S$ and $S / M$, there was a significant reduction of DM digestibility when the level of substitution increased.

Total tract digestibility of protein was higher in the control $\operatorname{diet}(81.50 \pm 0.85 \%)$ compared with all other treatments. M$(77.09 \pm 0.62 \%)$ and $\mathrm{S} / \mathrm{M}$-based diets $(77.89 \pm 0.54 \%)$ were significantly lower than the control diet whereas S-based diets $(79.35 \pm 0.32 \%)$ were not significantly different. Total tract digestibility of protein in S- and M-based diets tended to decrease linearly with the increasing level of substitution of corn. However, there was no effect of the level of substitution on total tract digestibility of protein when both sorghum and millet are simultaneously used in the diet.

No significant differences were observed between the control diet $(82.23 \pm 1.64 \%)$ and the experimental treatments. However, S-based diets $(79.82 \pm 0.46 \%)$ showed lower total tract digestibility of fat compared with $\mathrm{M}-(83.30 \pm 0.42 \%)$ and 
S/M-based diets $(83.83 \pm 0.62 \%)$. The level of substitution of sorghum or millet did not impact the total tract digestibility of fat. However, the combination of these two ingredients in broiler diet significantly affected fat digestibility with the highest level in the S30/M30 diet and the lowest level with the S50/M50 diet.

Higher total tract digestibility of starch was obtained with the control diet $(97.21 \pm 0.17 \%)$ and M-based diets $(97.17 \pm 0.14 \%)$ compared with the S-based diets $(95.66 \pm 0.22 \%)$. Total tract digestibility of starch in S/Mbased diets was intermediate $(96.28 \pm 0.16 \%)$ and not different from the control diet. The level of substitution of millet tended to affect total tract digestibility of starch whereas a significant reduction was observed when the level of substitution increased in S and S/M-based diets.

The treatment significantly affected AMEn with the highest values obtained with M-based diets $(13.38 \pm 0.05 \mathrm{MJ} / \mathrm{kg} \mathrm{DM})$. Results observed with the control diet $(13.26 \pm 0.07 \mathrm{MJ} / \mathrm{kg} \mathrm{DM})$ were similar to $\mathrm{S}$ - $(13.11 \pm 0.03 \mathrm{MJ} / \mathrm{kg} \mathrm{DM})$ and S/M-based diets $(13.29 \pm 0.05 \mathrm{MJ} / \mathrm{kg} \mathrm{DM})$. AMEn tended to decrease $(P=0.06)$ with the level of substitution in sorghum-based diets. No dose-response effect was found in millet or when this latter was mixed with sorghum.

\section{Discussion}

Partial or total substitution of corn by sorghum and millet, and soybean meal replacement by cottonseed meal had no significant effect on broiler's feed intake and growth performance. This is in accordance with reports of Jacob et al. (1996), Hidalgo et al. (2004) and Azman and Yilmaz (2005). However, these results are not in agreement with those reported by Jacobs and Parsons (2013) who observed a reduction in feed efficiency with sorghum-based diets, and related it to the feed particle size, which induces a higher feed intake. However, the present findings confirm the results obtained with the meta-analysis (Batonon-Alavo et al., 2015) in which no significant difference in feed intake was observed between sorghum- or millet-based diets and corn-based diets, and between cottonseed meal and control diets. However, sorghum-based diets increased FCR in Experiment 1 while no difference was found between the control- and sorghum-based diets in Experiment 2. In both experiments, there were differences between formulated and calculated ME and CP contents in all treatments (Tables 2 and 3). This is because estimated ME and CP contents of major feed ingredients were used in formulating diets and these differ from determined $\mathrm{CP}$ contents and recalculated ME contents based on the laboratory determination of starch, sugar and fat. The trend of higher feed consumption in sorghum-based diets in Experiment 1 could then be related to their lower recalculated ME content $(11.9 \mathrm{MJ} / \mathrm{kg})$ compared with the control diet $(12.3 \mathrm{MJ} / \mathrm{kg})$. In addition, sorghum-based diets were lower in analyzed fat content $(39.3 \pm 1.65 \mathrm{~g} / \mathrm{kg})$ than the control diet $(53.4 \mathrm{~g} / \mathrm{kg})$ in Experiment 1 . Since bird tend to decrease its consumption with the level of energy in the diet (Pérez-Bonilla et al., 2012) it is possible that ME and fat contents contributed to explain the increased FCR observed in sorghum-based diets in Experiment 1 instead of the sorghum effect per se. In addition, there was no difference in lysine intake and Met + Cyst intake. Therefore, no deficiency in these amino acids seems to exist with young birds.

Another aim of this study was to evaluate the effects of simultaneous inclusion of sorghum and cottonseed meal or millet on broiler performance and nutrient digestibility. Most substitution studies involved only one ingredient and interactions are therefore not studied (Hidalgo et al., 2004; Azman and Yilmaz, 2005). The present results showed that a combination of cottonseed meal and sorghum in the same diet did not decrease bird performance. Simultaneous replacement of corn by sorghum and millet also resulted in equivalent performance as the control diet. However, significant differences were observed in AID of protein and energy between feed ingredients, with the cottonseed meal- and sorghum/cottonseed meal-based diets having lower protein and energy digestibility than corn-based diets (Experiment 1). These results are consistent with those reported by Li et al. (2012) and Gonzalez-Vega and Stein (2012) who observed a decline in nitrogen and energy digestibility of growing and finishing pigs fed with various sources of cottonseed meal. Free gossypol in cottonseed meal is known to have an inhibitory action on certain enzymes in bird gastrointestinal tract like pepsinogen, pepsin and trypsin by binding with their free epsilon amino groups of lysine, thus reducing protein digestibility (Sharma et al., 1978). However, in this study free gossypol levels were too low (5 to $13 \mathrm{ppm}$ ) to induce any detrimental effect on growth performance (Nagalakshmi et al., 2007); but the effect of free gossypol could not be excluded from the reduction of digestibility with cottonseed meal-based diets. Similarly, lower total tract digestibility of fat and starch and lower AMEn values were obtained with sorghum-based diets consistently with previous reports (Selle et al., 2010; Mahmood et al., 2014) where digestibility coefficients were found inferior in sorghum than in other cereals due to the presence of phytate and phenolic compounds. Despite the lower fat and starch digestibility, our results suggest that birds fed low tannin sorghum-based diets were able to demonstrate equivalent performance as the control group since protein was equivalently available for both groups. Birds in millet-based diets have the same ability as those in corn-based diets to metabolize the energy and have a good feed efficiency. Higher coefficients of digestibility were obtained in millet-based diets consistently with Yin et al. (2002) and Baurhoo et al. (2011) and might be the factors leading to equivalent performance to the control diets.

Slaughtering method can have an effect on the results when digestibility is estimated by collection in the digestive tract. It should be noted that in the current study, birds were killed by cervical dislocation. Despite a debate on the best method of slaughtering the birds (i.e. cervical dislocation $v$. $\mathrm{CO}_{2}$ asphyxiation) in ileal collection, Poureslami et al. (2012) suggest that cervical dislocation, by the means of cutting off 
the nervous stimulation from the brain to the gut, might actually slow or stop peristalsis sooner and therefore is more advantageous than asphyxiation slaughtering method.

The results obtained in the two experiments also suggest that the level of substitution of the experimental feed ingredients does not affect broiler performance, thus confirming the meta-analytic findings (Batonon-Alavo et al., 2015). Corn can be partially replaced by sorghum (Experiment 1) or totally substituted by sorghum or millet without any damages on bird performance consistently with several authors (Davis et al., 2003; Manwar and Mandal, 2009). Likewise, soybean meal substitution at various levels by cottonseed meal did not impact bird's response. However, the present study demonstrated that nutrient digestion can be compromised with these feed ingredients. The inclusion of exogenous enzymes in poultry diets is an established practice to improve performance and proteases are of particular relevance since they can be used to reduce the levels of trypsin inhibitors and lectins, thus improving protein digestibility (Bedford and Partridge, 2010). Other feed processing technologies like hydrothermal processes combined with reducing agents may enhance the solubility and digestibility of sorghum protein by either cleaving disulphide linkages or preventing their formation (Liu et al., 2013). Consequently, further investigations are required on the best strategies to enhance the nutritional value of these feed ingredients and lead to an increasing utilization in poultry.

\section{Acknowledgements}

The authors are grateful to the poultry research team of the Research Center for Animal Nutrition and Health (CRNA), DSM Nutritional Products France for their technical assistance as well as their full commitment in the data collection. The authors also thank CIRAD SELMET laboratory staff, Laurent Bonnal and Elodie Baby for the chemical analyses.

\section{References}

Adeola 0 and Orban JI 1995. Chemical composition and nutrient digestibility of pearl millet (Pennisetum glaucum) fed to growing pigs. Journal of Cereal Science 22, 177-184.

AOAC International 1995. Official methods of analysis vol. 2, 16th edition. Association of Analytical Communities, Arlington, VA, USA.

Aviagen 2007. Broiler Ross 308: nutrition specifications. Aviagen, Scotland, UK, 8pp.

Azman MA and Yilmaz M 2005. The growth performance of broiler chicks fed with diets containing cottonseed meal supplemented with lysine. Revue de Médecine Vétérinaire 156, 104-106.

Bastianelli D, Bonnal L, Juin H, Mignon-Grasteau S, Davrieux F and Carré B 2010. Prediction of the chemical composition of poultry excreta by near infrared spectroscopy. Journal of Near Infrared Spectroscopy 18, 69-77.

Batonon-Alavo DI, Umar Faruk M, Lescoat P, Weber GM and Bastianelli D 2015. Inclusion of sorghum, millet and cottonseed meal in broiler diets: a meta-analysis of effects on performance. Animal 9, 1120-1130.

Baurhoo N, Baurhoo B, Mustafa AF and Zhao X 2011. Comparison of corn-based and Canadian pearl millet-based diets on performance, digestibility, villus morphology, and digestive microbial populations in broiler chickens. Poultry Science 90, 579-586.

Bedford MR and Partridge GG 2010. Enzymes in farm animal nutrition. CAB International, London, UK.
Davis AJ, Dale NM and Ferreira FJ 2003. Pearl millet as an alternative feed ingredient in broiler diets. Journal of Applied Poultry Research 12, 137-144.

Fisher $C$ and McNab JM 1987. Techniques for determining the ME content of poultry feeds. In Recent advances in animal nutrition (ed. W Haresign and DJA Cole), pp. 3-17. Butterworths, London.

Flores MP, Castañon JIR and McNab JM 1994. Effect of tannins on starch digestibility and TME of triticale and semi purified starches from triticale and field beans. British Poultry Science 35, 281-286.

Gonzalez-Vega JC and Stein HH 2012. Amino acid digestibility in canola-, cottonseed- and sunflower-products fed to finishing pigs. Journal of Animal Science 90, 4391-4400.

Goodarzi Boroojeni F, Samie AH, Edriss MA, Khorvash M, Sadeghi G, Van Kessel A and Zentek J 2011. Replacement of corn in the diet of broiler chickens using foxtail millet produced by 2 different cultivation strategies. Poultry Science 90 , 2817-2827.

Heuzé $V$ and Tran $G$ 2012. Pearl millet (Pennisetum glaucum) grain. Feedipedia. org. A programme by INRA, CIRAD, AFZ and FAO. Retrieved August 8, 2014, from http://www.feedipedia.org/node/724.

Hidalgo MA, Davis AJ, Dale NM and Dozier III WA 2004. Use of whole pearl millet in broiler diets. Journal of Applied Poultry Research 13, 229-234.

Hill FW and Anderson DL 1958. Comparison of metabolizable energy and productive energy determinations with growing chicks. Journal of Nutrition 64 , 587-603.

Jacob JP, Mitaru BN, Mbugua PN and Blair R 1996. The effect of substituting Kenyan Serena sorghum for maize in broiler starter diets with different dietary crude protein and methionine levels. Animal Feed Science and Technology 61, 27-39.

Jacobs C and Parsons CM 2013. The effects of coarse ground corn, whole sorghum, and a prebiotic on growth performance, nutrient digestibility, and cecal microbial populations in broilers fed diets with and without corn distillers dried grains with solubles. Poultry Science 92, 2347-2357.

Janssen WMMA 1989. European table of energy values for poultry feedstuffs, 3rd edition. Spelderholt Center for Poultry Research and Information Services, Beekbergen, The Netherlands.

Li JT, Li DF, Zang JJ, Yang WJ, Zhang WJ and Zhang LY 2012. Evaluation of energy digestibility and prediction of digestible and metabolizable energy from chemical composition of different cottonseed meal sources fed to growing pigs. Asian-Australian Journal of Animal Science 25, 1430-1438.

Liu SY, Selle PH and Cowieson AJ 2013. Strategies to enhance the performance of pigs and poultry on sorghum-based diets. Animal Feed Science and Technology 181, 1-14.

Mahmood S, Ali H, Ahmad F and Iqbal Z 2014. Estimation of tannins in different sorghum varieties and their effects on nutrient digestibility and absorption of some minerals in caged white leghorn layers. International Journal of Agriculture and Biology 16, 217-221.

Mahmood S, Khan MA, Sarwar M and Nisa M 2006. Chemical treatments to reduce antinutritional factors in salseed (Shorea robusta) meal: effect on nutrient digestibility in colostomized hens and intact broilers. Poultry Science 85, 2207-2215.

Manwar SJ and Mandal AB 2009. Effect of high moisture storage of pearl millet (Pennisetum typhoides) with or without feed enzymes on growth and nutrient utilization in broiler chickens. Animal Science Journal 80, 438-445.

Nagalakshmi D, Rama Rao SV, Panda AK and Sastry VRB 2007. Cottonseed meal in poultry diets: a review. The Journal of Poultry Science 44, 119-134.

Pérez-Bonilla A, Novoa S, García J, Mohiti-Asli M, Frikha M and Mateos GG 2012. Effects of energy concentration of the diet on productive performance and egg quality of brown egg-laying hens differing in initial body weight. Poultry Science 91, 3156-3166.

Poureslami R, Batal AB and Jung B 2012. Effect of ileal sub-section and the method of collection of digesta on the determination of apparent ileal digestibility of amino acids in broilers. Animal Feed Science and Technology 177, 130-133.

$R$ Core Team 2013. R: a language and environment for statistical computing. $R$ Foundation for Statistical Computing, Vienna, Austria.

Sauvant D, Perez JM and Tran G 2004. Tables of composition and nutritional value of feed materials, INRA Editions and AFZ. Wageningen Academic Publishers, Paris, France.

Selle PH, Cadogan DJ, Li X and Bryden WL 2010. Implications of sorghum in broiler chicken nutrition. Animal Feed Science and Technology 156, 57-74. 
Sharma NK, Lodhi GN and Ichhponani JS 1978. Comparative feeding value of expeller processed undecorticated and decorticated cottonseed cakes for growing chicks. Journal of Agricultural Science 91, 531-541.

Siegel S and Castellan NJ 1988. Non parametric statistics for the behavioral sciences. MacGraw Hill Int., New York, NY, USA.

Terpstra K and de Hart N 1974. The estimation of urinary nitrogen and faecal nitrogen in poultry excreta. Zeitschrift für Tierphysiologie Tierernährung und Futtermittelkunde $32,306-320$.
Van Soest PJ and Wine RH 1967. Use of detergents in the analysis of fibrous feeds. IV. Determination of plant cell walls constituents. Journal of the Association of Official Analytical Chemists 50, 50-55.

Yin YL, Gurung NK, Jeaurond EA, Sharpe PH and de Lange CFM 2002. Digestible energy and amino acid contents in Canadian varieties of sorghum, pearl millet, high-oil corn, high-oil-high-protein corn and regular corn samples for growing pigs. Canadian Journal of Animal Science 82, 385-391. 